\title{
Swainsona Formosa (G.Don) Joy Thomp. Solvent Extractions Inhibit the Growth of a Panel of Pathogenic Bacteria
}

Getmore Rumbudzai Chikowe', Lindiwe Nomathemba Mpala', Ian Edwin Cock ${ }^{1,2^{*}}$

'School of Natural Sciences, Griffith University, 170 Kessels Rd, Nathan, Brisbane, Queensland 4111, AUSTRALIA

2Environmental Futures Research Institute, Griffith University, 170 Kessels Rd, Nathan, Brisbane, Queensland 4111, AUSTRALIA

\begin{abstract}
Introduction: Swainsona formosa is a legumous plant which is endemic to the arid inland regions of Australia. Several Swainsona spp. were valued by the first Australian for their antiseptic properties and were used traditionally to treat a variety of bacterial diseases. Despite this, $S$. formosa solvent extractions have not been rigorously examined for antibacterial properties against many bacterial pathogens. Methods: The antimicrobial activity of S. formosa leaf extracts was investigated by disc diffusion and growth time course assays against a panel of pathogenic bacteria. The growth inhibitory activity was quantified by MIC determination. Toxicity was determined using the Artemia franciscana nauplii bioassay. Results: S. formosa leaf extracts inhibited the growth of a wide range of gram positive and gram negative bacteria. The methanolic extracts were generally more potent than the aqueous extracts. The methanolic and aqueous $S$. formosa leaf extracts were particularly potent inhibitors of $A$. faecalis, A. hydrophilia, K. pneumoniae, P. mirabilis, B. cereus, S. aureus and S. pyogenes growth, with MIC values substantially $<1000 \mu \mathrm{g} / \mathrm{mL}$ and as low as $150 \mu \mathrm{g} / \mathrm{mL}$ against some bacteria (methanolic extract against $P$. mirabilis). The antibacterial activity of the methanolic and aqueous $S$. formosa leaf extracts was fur-
\end{abstract}

ther investigated by growth time course assays which showed significant growth inhibition in cultures of all bacterial species within $1 \mathrm{~h}$ of exposure. All extracts were determined to be nontoxic in the Artemia franciscana nauplii bioassay, indicating their safety for therapeutic uses. Conclusions: The lack of toxicity of the $S$. formosa leaf extracts and their growth inhibitory bioactivity against a panel of pathogenic bacteria indicate their potential in the development of antiseptic agents.

Key words: Sturts Desert Pea, Fabaceae, Swainsonine, N,N-Dimethyltryptamine, Australian Plants, Antibacterial Activity, Medicinal Plants.

Correspondence:

Ian Edwin Cock,

School of Natural Sciences, Griffith University, 170 Kessels Rd, Nathan, Brisbane, Queensland 4111, AUSTRALIA \& Environmental Futures Research Institute, Griffith University, 170 Kessels Rd, Nathan, Brisbane, Queensland 4111, AUSTRALIA.

Tel : +61 7 37357637; Fax: +61 737355282

E-mail: I.Cock@griffith.edu.au (I. E. Cock).

DOI : $10.5530 /$ pc.2017.2.13

\section{INTRODUCTION}

Bacterial resistance to conventional antibiotics is a concern to public health. ${ }^{1}$ The development of super resistant bacterial strains is resulting in currently used antibiotic agents failing to end many bacterial pathogen infections. For this reason the search is ongoing for new antimicrobial agents, either by the design and synthesis of new agents, or through the search of natural sources for as yet undiscovered antimicrobial agents. The growth inhibitory qualities of medicinal plants against pathogenic bacteria have been long recognised. Recently there has been a revival of interest in herbal medications due to a perception that there is a lower incidence of adverse reactions to plant preparations compared to synthetic pharmaceuticals. ${ }^{2}$ The first Australians had well developed ethnopharmacological systems and understood the therapeutic properties of a wide variety of aromatic Australian plants. ${ }^{3}$ Despite this, relatively few studies have rigorously examined the antibacterial activity of many Australian native plants. However, recently there has been increased study in this field. ${ }^{4-7}$

Swainsona formosa (G.Don) Joy Thomps. (family Fabaceae; synonyms Clianthus formosus (G.Don) Ford \& Vickery, Clianthus dampieri Lindl., Clianthus oxleyi A.Cunn. ex Lindl.; commonly known as Sturts desert pea) is a low growing or prostrate legume which is endemic to arid inland regions of the Australian continent. Its taxonomy is somewhat confused, with the species name changing at least 9 names since its original naming as Clianthus dampieri Lindl. in the early part of the $18^{\text {th }}$ century. Since that time, it has been reclassified under 3 separate genera (Clianthus, Donia and Swainsona) and was recently proposed to be classified as Willdampia formosa (G.Don) A.S.George, although this reclassification has since been rejected. Despite the taxonomic ambiguity, this species is most closely aligned with the genus Swainsona on the basis of morphology, genetics and chemotaxonomic similarities. S. formosa has a distinctive appearance, with showy blood red flowers with a bulbous black centre (Figure 1a). It is perhaps best known as the state floral emblem for the state of South Australia.

Several Swainsona spp. were used by Australian Aborigines as traditional medicines. ${ }^{3-8}$ Swainsona galegifolia (Andrews) R.Br. and Swainsona pterostylis (DC.) Bakh.f. were considered particularly useful as antiseptics and as bacteriocide chemotherapies against a broad spectrum of bacterial pathogens. ${ }^{3-8}$ Interestingly, we were unable to find confirmed reports of Aboriginal medicinal use of $S$. formosa for similar purposes. However, a defining phytochemical characteristic of many Swainsona spp. is the presence of the indolizidine alkaloid phytotoxin swainsonine (Figure 1b). ${ }^{9}$ Swainsonine has been associated with livestock intoxication via inhibition of the enzymes $\alpha$-mannosidase and mannosidase II which are required for processing and maturation of $\mathrm{N}$-linked oligosaccharides of newly synthesised glycoproteins. To date, most interest in the therapeutic properties of swainsonine have focussed on its potential as a cancer chemotherapeutic drug via a reduction of tumour cell metastatis, decreased proliferation and enhanced cellular immune responses. ${ }^{10}$ Interestingly, many pathogenic bacteria also contain $\mathrm{N}$-glycosylates attached to their surface proteins. ${ }^{11,12}$ Despite the ability of swainsonine to disrupt this process, there is a lack of studies examining the growth inhibitory properties of swainsonine, or of extracts containing this compound.

S. formosa has also been reported to produce significant quantities of N,N-dimethyltryptamine (DMT; Figure 1c). ${ }^{13}$ The presence of DMT in some Australian plants (including S. formosa) is interesting and has resulted in the failed attempt by the Australian government in 2011/2012 to introduce legislation banning the growing of many DMT containing plants, including the floral emblem of South Australia (S. formosa) and 


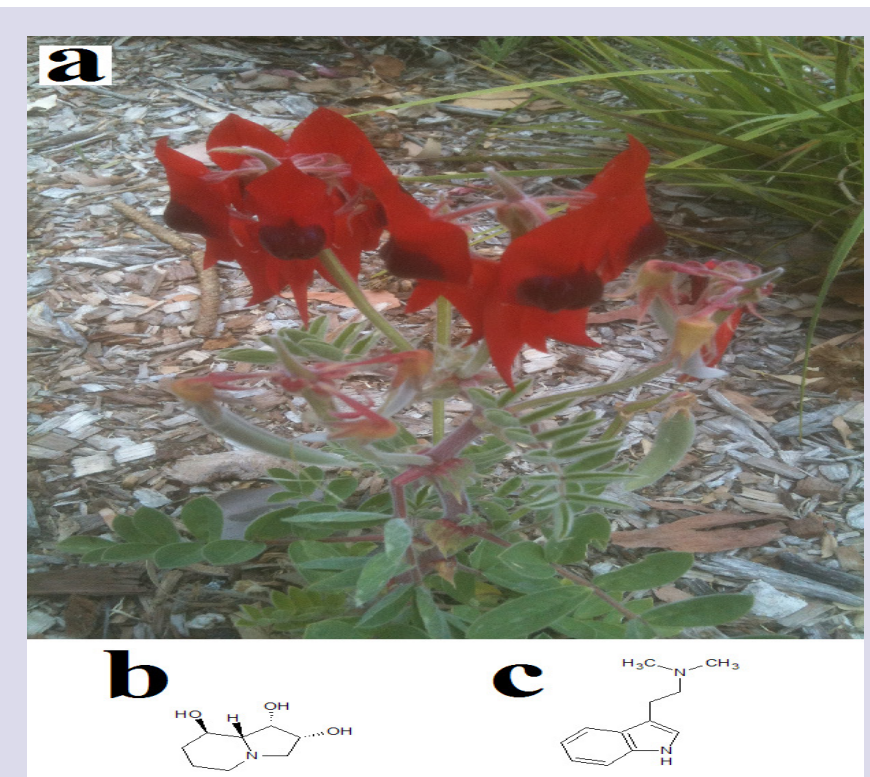

Figure 1: (a) Swainsona formosa whole plant and the chemical constituents (b) swainsonine and (c) N,N-dimethyltryptamine.

the Australian floral emblem (Acacia pycnantha; golden wattle). Whilst DMT is best known for its psychedelic properties, several DMT derivatives have potent antimicrobial activity. ${ }^{14}$ Despite its interesting phytochemistry and the ethnobotanical usage of other Swainsona spp. as antiseptics, studies examining the bacterial growth inhibitory properties of $S$. formosa are lacking. The current report was undertaken to screen $S$. formosa leaf extracts for growth inhibitory properties against a panel of pathogenic bacteria.

\section{MATERIALS AND METHODS}

\section{Plant collection and extraction}

Swainsona formosa (G.Don) Joy Thomp. leaves were obtained from and identified by Philip Cameron, senior botanic officer, Mt Cootha Botanical Gardens, Brisbane, Australia. The leaf samples were dried in a Sunbeam food dehydrator and stored at $-30{ }^{\circ} \mathrm{C}$. Prior to use, the dried leaves were freshly ground to a coarse powder and $1 \mathrm{~g}$ quantities were weighed into separate tubes. A volume of $50 \mathrm{~mL}$ methanol, sterile deionised water, ethyl acetate, chloroform or hexane was added to individual tubes and extracted for 24 hours at $4{ }^{\circ} \mathrm{C}$ with gentle shaking. All solvents were obtained from Ajax, Australia and were AR grade. The extracts were filtered through filter paper (Whatman No. 54) under vacuum, followed by drying by rotary evaporation in an Eppendorf concentrator 5301 . The resultant pellets were dissolved in $10 \mathrm{~mL}$ sterile deionised water (containing $1 \% \mathrm{DMSO}$ ). The extracts were passed through $0.22 \mu \mathrm{m}$ filter (Sarstedt) and stored at $4{ }^{\circ} \mathrm{C}$ until use.

\section{Qualitative phytochemical studies}

Phytochemical analysis of the $S$. formosa leaf extracts for the presence of saponins, phenolic compounds, flavonoids, phytosteroids, triterpenoids, cardiac glycosides, anthraquinones, tannins and alkaloids was conducted by previously described assays. ${ }^{15-17}$

\section{Antibacterial screening}

\section{Test microorganisms}

All media was supplied by Oxoid Ltd., Australia. Clinical isolate microbial strains of Aeromonas hydrophilia, Alcaligenes feacalis, Bacillus cereus, Citrobacter freundii, Escherichia coli, Klebsiella pneumoniae, Proteus mirabilis, Pseudomonas fluorescens, Salmonella newport, Serratia marcescens, Shigella sonneii, Staphylococcus aureus, Staphylococcus epidermidis and Streptococcus pyonenes were obtained from Ms Michelle Mendell and Ms Jane Gifkins, Griffith University. All stock cultures were subcultured and maintained in nutrient broth at $4{ }^{\circ} \mathrm{C}$.

\section{Evaluation of antimicrobial activity}

Antimicrobial activity of all plant extracts was determined using a modified disc diffusion assay. ${ }^{18-20}$ Briefly, $100 \mu \mathrm{L}$ of each bacterial culture was grown in $10 \mathrm{~mL}$ of fresh nutrient broth until they reached a count of $\sim 10^{8}$ cells $/ \mathrm{mL}$. A volume of $100 \mu \mathrm{L}$ of the bacterial suspension was spread onto nutrient agar plates and extracts were tested for antibacterial activity using $5 \mathrm{~mm}$ sterilised filter paper discs. Discs were infused with $10 \mu \mathrm{L}$ of the plant extracts, allowed to dry and placed onto the inoculated plates. The plates were allowed to stand at $4{ }^{\circ} \mathrm{C}$ for $2 \mathrm{~h}$ before incubation at $30^{\circ} \mathrm{C}$ for $24 \mathrm{~h}$. The diameters of the inhibition zones were measured to the closest whole millimetre. Each assay was performed in at least triplicate. Mean values ( \pm SEM) are reported in this study. Standard discs of ampicillin $(10 \mu \mathrm{g})$ were obtained from Oxoid, Australia and were used as positive controls to compare antibacterial activity. Filter discs infused with $10 \mu \mathrm{L}$ of distilled water were used as a negative control.

\section{Minimum inhibitory concentration (MIC) determination}

The minimum inhibitory concentration (MIC) of each extract against susceptible bacteria was determined as previously described. ${ }^{21,22}$ Briefly, the $S$. formosa extracts were diluted in deionised water and tested across a range of concentrations. Discs were infused with $10 \mu \mathrm{L}$ of the test dilutions, allowed to dry and placed onto inoculated plates. The assay was completed as outlined above and graphs of the zone of inhibition versus concentration were plotted for each extract. Linear regression was used to determine the MIC values of each extract.

\section{Bacterial growth time course assay}

Bacterial growth time course studies were performed as previously described. ${ }^{23,24}$ Briefly, $3 \mathrm{~mL}$ of the most susceptible bacterial cultures ( $K$. pneumoniae, $P$. mirabilis and $B$. cereus) in nutrient broth were added to $27 \mathrm{~mL}$ nutrient broth containing $3 \mathrm{~mL}$ of $10 \mathrm{mg} / \mathrm{mL}$ methanolic plant extract to give a final concentration of $1000 \mu \mathrm{g} / \mathrm{mL}$ in the assay. The tubes were incubated at $30{ }^{\circ} \mathrm{C}$ with gentle shaking. The optical density was measured hourly at $550 \mathrm{~nm}$ for a $6 \mathrm{~h}$ incubation period. Control tubes were incubated under the same conditions but without the extract. All assays were performed in triplicate.

\section{Toxicity screening}

\section{Reference toxin for toxicity screening}

Potassium dichromate $\left(\mathrm{K}_{2} \mathrm{Cr}_{2} \mathrm{O}_{7}\right)$ (AR grade, Chem-Supply, Australia) was prepared as a $4 \mathrm{mg} / \mathrm{mL}$ solution in distilled water and was serially diluted in artificial seawater for use in the Artemia franciscana nauplii bioassay.

\section{Artemia franciscana nauplii toxicity screening}

Toxicity was tested using an adapted Artemia franciscana nauplii lethality assay. ${ }^{25-27}$ Briefly, $400 \mu \mathrm{L}$ of seawater containing approximately 62 (mean 61.7, $\mathrm{n}=85, \mathrm{SD} 11.6$ ) A. franciscana nauplii were added to wells 
Table 1: The mass of dried extracted material, the concentration after resuspension in deionised water and qualitative phytochemical screenings of the $S$. formosa extracts.

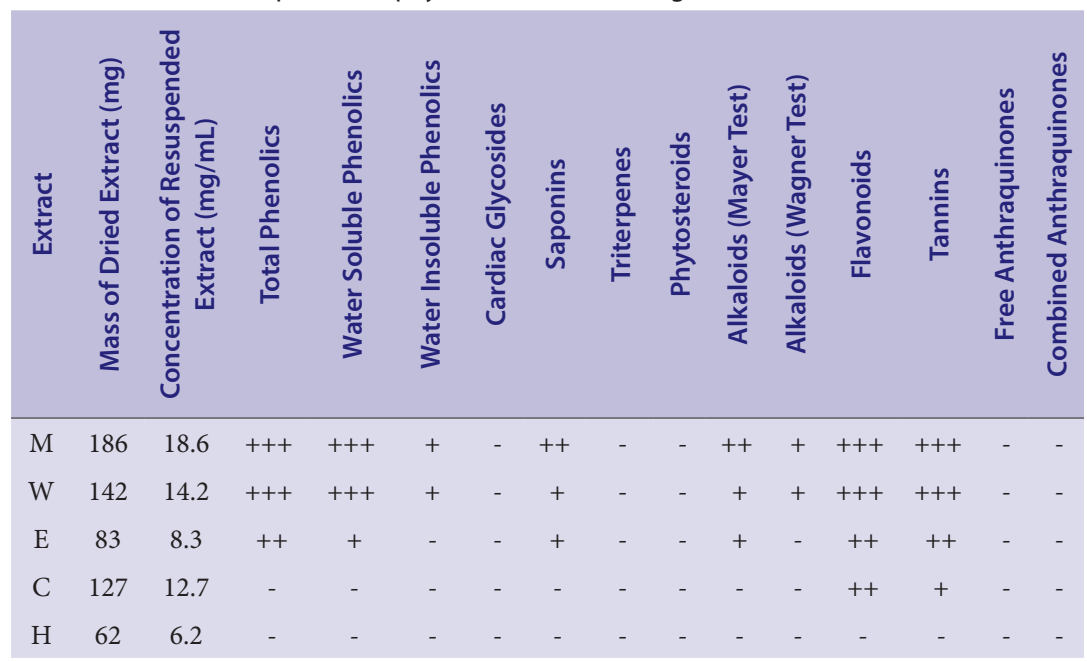

+++ indicates a large response; ++ indicates a moderate response; + indicates a minor response; - indicates no response in the assay. $\mathrm{M}=$ methanolic extract; $\mathrm{W}=$ aqueous extract; $\mathrm{E}=$ ethyl acetate extract; $\mathrm{C}=$ chloroform extract; $\mathrm{H}=$ hexane extract.

of a 48 well plate and immediately used for bioassay. A volume of 400 $\mu \mathrm{L}$ of diluted plant extracts or the reference toxin were transferred to the wells and incubated at $25 \pm 1{ }^{\circ} \mathrm{C}$ under artificial light (1000 Lux). A $400 \mu \mathrm{L}$ seawater negative control was run in triplicate for each plate. All treatments were performed in at least triplicate. The wells were checked at regular intervals and the number of dead counted. The nauplii were considered dead if no movement of the appendages was detected within 10 seconds. After $24 \mathrm{~h}$, all nauplii were sacrificed and counted to determine the total $\%$ mortality per well. The $\mathrm{LC}_{50}$ with $95 \%$ confidence limits for each treatment was determined using probit analysis.

\section{Statistical analysis}

Data are expressed as the mean \pm SEM of at least three independent experiments. One way ANOVA was used to calculate statistical significance between control and treated groups with a $P$ value $<0.01$ considered to be statistically significant.

\section{RESULTS}

\section{Liquid extraction yields and qualitative phytochemical screening}

Extraction of $1 \mathrm{~g}$ of dried and powdered S. formosa leaves with solvents of varying polarity yielded dried extracts ranging from $62 \mathrm{mg}$ (hexane extract) to $186 \mathrm{mg}$ (methanol extract) (Table 1). The aqueous (142 mg) and chloroform extracts $(127 \mathrm{mg})$ also yielded relatively high levels of extracted materials. The dried extracts were resuspended in $10 \mathrm{~mL}$ of deionised water (containing 1\% DMSO), resulting in the extract concentrations shown in Table 1.

Qualitative phytochemical studies showed that the higher polarity methanol and water solvents extracted the greatest diversity and highest levels of phytochemicals. Both contained high levels of phenolics, flavonoids and tannins as well as moderate levels of saponins and alkaloids. The ethyl acetate extract contained similar phytochemical classes, albeit generally at lower levels. Interestingly, despite extracting relatively large amounts of material, the chloroform and hexane extracts
Table 2: Minimum bacterial growth inhibitory concentration $(\mu \mathrm{g} / \mathrm{mL})$ of the S. formosa extracts.

\begin{tabular}{cccccc} 
Bacterial Species & M & W & E & C & H \\
\hline Gram negative bacteria & & & & & \\
\hline A. faecalis & 468 & 783 & - & - & - \\
A. hydrophilia & 640 & 1044 & 926 & - & - \\
C. freundii & - & - & - & - & - \\
E. coli & - & - & - & - & - \\
K. pneumoniae & 166 & 375 & 880 & - & - \\
P. mirabilis & 141 & 168 & 743 & 947 & - \\
P. fluorescens & - & - & - & - & - \\
S. newport & - & - & - & - & - \\
S. marcescens & - & - & - & - & - \\
S. sonneii & - & - & - & - & - \\
Gram positive bacteria & & & & & \\
\hline B. cereus & 328 & 855 & 1163 & 1870 & - \\
S. aureus & 575 & 927 & 1045 & - & - \\
S. epidermidis & - & - & - & - & - \\
S. pyonenes & 622 & 1449 & - & - & -
\end{tabular}

Numbers indicate the mean MIC and $\mathrm{LC}_{50}$ values of triplicate determinations. - indicates no inhibition. 


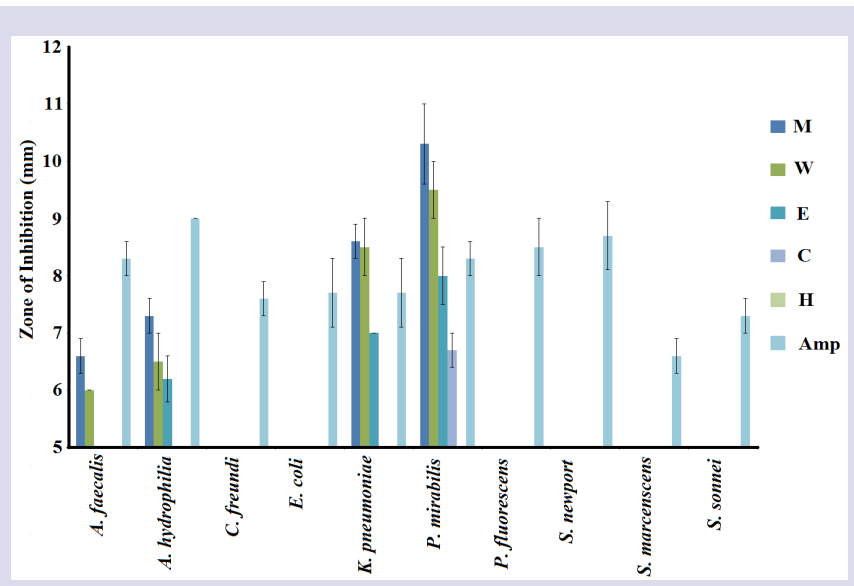

Figure 2: Growth inhibitory activity of $S$. formosa leaf extracts against gram negative bacterial species. $\mathrm{M}=$ methanolic extract; $\mathrm{W}=$ aqueous extract; $\mathrm{E}=$ ethyl acetate extract; $\mathrm{C}=$ chloroform extract; $\mathrm{H}=$ hexane extract; $\mathrm{Amp}=$ ampicillin $(10 \mu \mathrm{g})$ control. All determinations were performed in at least triplicate and the results are expressed as mean zones of inhibition $(\mathrm{mm}) \pm$ SEM.

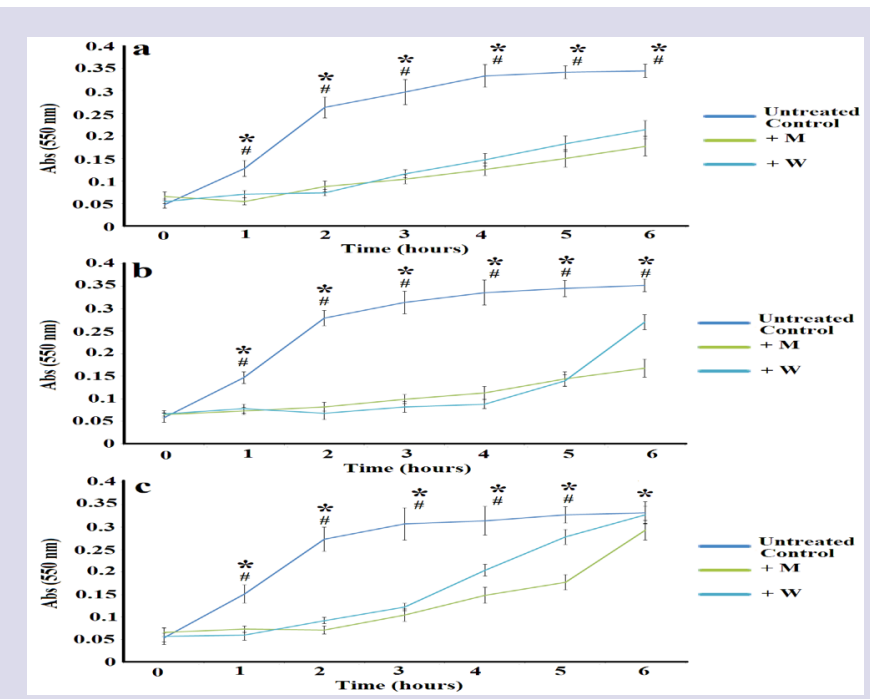

Figure 4: Bacterial growth curves for the methanolic and aqueous $S$. formosa extracts against (a) K. pneumoniae, (b) P. mirabilis and (c) B. cereus. All bioassays were performed in at least triplicate and are expressed as mean \pm SEM. ${ }^{*}=$ growth results in the presence of the methanolic extract that are significantly different to the untreated control growth $(p<0.01)$; \# = growth results in the presence of the aqueous extract that are significantly different to the untreated control growth $(p<0.01)$.

were devoid of all classes of phytochemicals screened. Due to their nonpolar nature, these extracts would be expected to contain high levels of lipids, hydrocarbons etc. As our qualitative phytochemical studies did not screen for these compounds, they were not detected and other techniques are required to further examine the nature of these nonpolar components.

\section{Antimicrobial activity}

To determine the growth inhibitory activity of the $S$. formosa leaf extracts against the panel of pathogenic bacteria, aliquots $(10 \mu \mathrm{L})$ of each extract were screened in the disc diffusion assay. The aqueous and methanolic $S$. formosa leaf extracts inhibited a broadest range of gram negative (Figure 2) and gram positive bacteria (Figure 3). The methanolic S. formosa

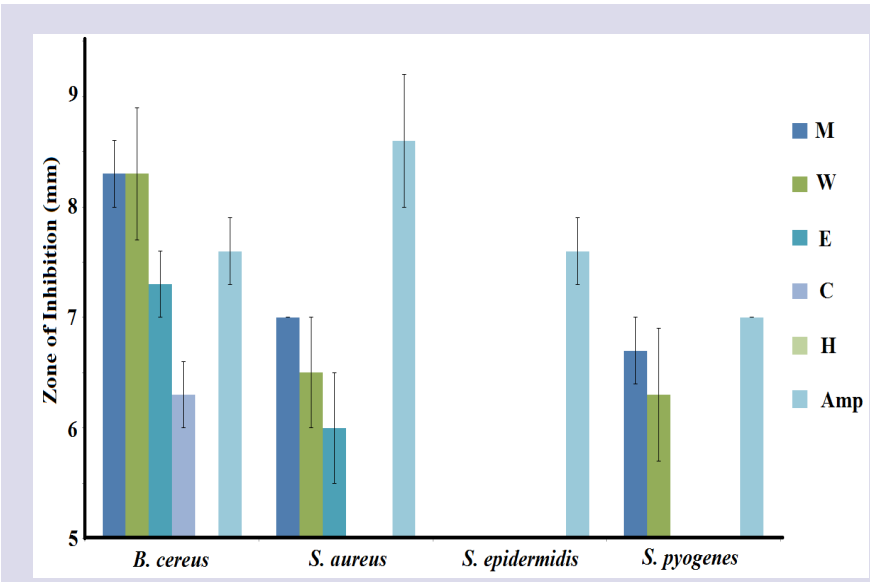

Figure 3: Growth inhibitory activity of $S$. formosa leaf extracts against gram positive bacterial species. $\mathrm{M}=$ methanolic extract; $\mathrm{W}=$ aqueous extract; $\mathrm{E}=$ ethyl acetate extract; $\mathrm{C}=$ chloroform extract; $\mathrm{H}=$ hexane extract; Amp = ampicillin $(10 \mu \mathrm{g})$ control. All determinations were performed in at least triplicate and the results are expressed as mean zones of inhibition $(\mathrm{mm}) \pm$ SEM.

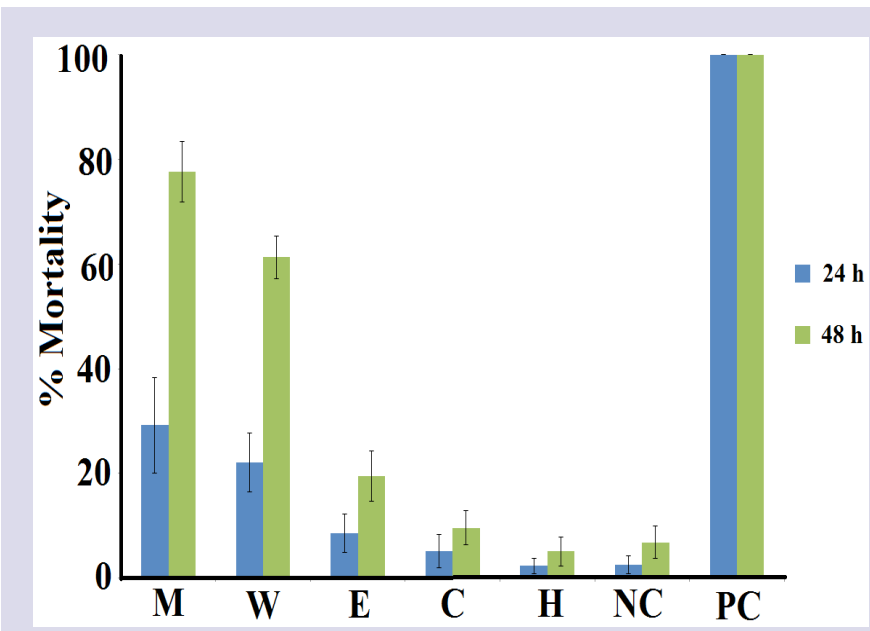

Figure 5: The lethality of the $S$. formosa leaf extracts $(2000 \mu \mathrm{g} / \mathrm{mL})$, potassium dichromate $(1000 \mu \mathrm{g} / \mathrm{mL})$ and a seawater control. $\mathrm{M}=$ methanolic extract; $\mathrm{W}=$ aqueous extract; $\mathrm{E}=$ ethyl acetate extract; $\mathrm{C}=$ chloroform extract; $\mathrm{H}=$ hexane extract; $\mathrm{NC}=$ negative (seawater) control; $\mathrm{PC}=$ positive control ( $1000 \mu \mathrm{g} / \mathrm{mL}$ potassium dichromate). All bioassays were performed in at least triplicate and are expressed as mean \pm SEM.

extract was a more potent growth inhibitor than the aqueous extract against most gram negative bacterial species (as assessed by the sizes of the zones of inhibition; Figure 2). The inhibition of the methanolic and aqueous extracts was particularly noteworthy against $K$. pneumoniae, $P$. mirabilis and $B$. cereus, with inhibition zones of approximately 8.5, 10 and $8.3 \mathrm{~mm}$ respectively for both extracts. This compares favourably to the inhibition by the ampicillin control $(10 \mu \mathrm{g}$ : inhibition zones of approximately $7.7,8.3$ and $7.6 \mathrm{~mm}$ against $K$. pneumoniae, $P$. mirabilis and $B$. cereus respectively). The ethyl acetate and chloroform extracts also inhibited the growth of a range of bacteria (5 (36\%) and 2 (14\%) of the 14 bacterial species tested respectively), albeit generally with substantially smaller inhibition zones than were recorded for methanolic and aqueous extracts. The hexane extract was devoid of growth inhibitory activity.

Gram positive bacteria were also susceptible to the $S$. formosa leaf extracts (Figure 3). Of the 4 gram positive bacterial strains tested, 3 (75 
$\%)$ were inhibited by both the methanolic and aqueous $S$. formosa leaf extracts. With the exception of $S$. pyogenes, all of these bacterial species were also inhibited by the ethyl acetate $S$. formosa leaf extract. The chloroform extract only inhibited B. cereus of the gram positive bacteria. Furthermore, the chloroform extract only produced a small zone of inhibition indicative of weak growth inhibitory activity. The hexane extract was devoid of bacterial growth inhibitory activity against all gram positive bacterial species.

The antimicrobial efficacy was further quantified by determining the MIC values for each extract against the microbial species which were determined to be susceptible. The methanolic, aqueous and ethyl acetate $S$. formosa leaf extracts were potent growth inhibitors of several bacterial species (as judged by MIC; Table 2). P. mirabilis was the most susceptible bacteria to the $S$. formosa leaf extracts, with MIC values $<175 \mu \mathrm{g} / \mathrm{mL}$ $(<2 \mu \mathrm{g}$ infused into the disc) recorded for the aqueous and methanolic extracts. The ethyl acetate and chloroform extracts was also good $P$. mirabilis growth inhibitor, with MIC values of $<1000 \mu \mathrm{g} / \mathrm{mL}$. As $P$. mirabilis infection is a common cause of urinary tract infections and has also been identified as a trigger of rheumatoid arthritis, ${ }^{28,29}$ the aqueous and methanolic $S$. formosa leaf extracts have potential for the prevention of these diseases in genetically susceptible individuals. The methanolic and aqueous extracts were similarly potent inhibitors of $K$. pneumoniae growth with MIC values 150-375 $\mu \mathrm{g} / \mathrm{mL}$. K. pneumoniae infections have been identified as a trigger for ankylosing spondylitis in genetically susceptible people, ${ }^{24}$ further highlighting the potential for the prevention and treatment of ankylosing spondylitis.

Furthermore, the aqueous and methanolic extracts were also potent $A$. faecalis, A. hydrophilia, S. aureus and S. pyogenes growth inhibitors, with MIC values generally in the $500-1000 \mu \mathrm{g} / \mathrm{mL}$ range. The ethyl acetate extract was also a potent $A$. hydrophilia growth inhibitor (MIC $926 \mu \mathrm{g} /$ $\mathrm{mL}$ ). The chloroform $S$. formosa extract also inhibited P. mirabilis and $B$. cereus growth, albeit with MIC values $>1000 \mu \mathrm{g} / \mathrm{mL}$, indicating moderate growth inhibition. Moderate to low growth inhibition (or no inhibition) was noted for all other extract/bacterium combinations.

\section{Bacterial growth time course assay}

The antibacterial activity of the $S$. formosa extracts was further investigated in K. pneumoniae, P. mirabilis and B. cereus by bacterial growth time course assays in the presence and absence of the extract. Only the effect of the methanolic and aqueous extracts on the bacterial growth time course were evaluated as these extracts were generally the most potent bacterial growth inhibitors. The starting concentration of the extract used in these assays was $1000 \mu \mathrm{g} / \mathrm{mL}$. The methanolic $S$. formosa extract significantly inhibited K. pneumoniae (Figure 4a), P. mirabilis (Figure 4b) and $B$. cereus growth (Figure $4 \mathrm{c}$ ) within $1 \mathrm{~h}$, indicating a rapid antimicrobial action. Whilst $B$. cereus growth was inhibited for at least the first 5 hours of the time course, the bacteria were generally able to overcome this inhibition by $6 \mathrm{~h}$, with the recorded turbidity not significantly different to that of the untreated control. This indicates that the growth inhibition of these bacteria was bacteriostatic for the methanolic and aqueous $S$. formosa extracts at the concentrations tested. In contrast, inhibition of K. pneumoniae and P. mirabilis by the methanolic and aqueous S. formosa extracts was substantially more profound, with growth still significantly inhibited by the end of the $6 \mathrm{~h}$ time course study for both bacteria. This may indicate that these extracts have bactericidal activity against these bacterial species at the dose tested. Indeed, the turbidity at $6 \mathrm{~h}$ was not greatly increased from the starting turbidity.

\section{Quantification of toxicity}

The toxicity of the S. formosa extracts was screened in the Artemia franciscana nauplii bioassay at a concentration of $2000 \mu \mathrm{g} / \mathrm{mL}$ (Figure 5).
All extracts induced low levels of mortality at $24 \mathrm{~h}$, similar to the \% mortality seen for the seawater control. By $48 \mathrm{~h}$, the aqueous and methanolic extracts had begun to induce mortality significantly higher than that in the untreated control. As only the methanolic extract induced $>$ $50 \%$ toxicity at $48 \mathrm{~h}$, all extracts were deemed to be nontoxic. Extracts with an $\mathrm{LC}_{50}$ of greater than $1000 \mu \mathrm{g} / \mathrm{mL}$ towards Artemia nauplii have previously been defined as being nontoxic, ${ }^{27}$ In contrast, the potassium dichromate positive control induced mortality within $4 \mathrm{~h}$ (results not shown), with $100 \%$ mortality induction seen by $24 \mathrm{~h}$.

\section{DISCUSSION}

Plant derived remedies are becoming increasingly sought after in the treatment of a myriad of diseases and disorders due both to their perception of greater safety than synthetic drugs, and the failure of current drug regimens to effectively treat many diseases. This study reports on the growth inhibitory properties of $S$. formosa leaf extracts against a panel of pathogenic bacteria, and on their toxicity. Both gram positive and gram negative bacteria tested in this study were susceptible to the $S$. formosa leaf extracts, although the gram positive bacteria were more susceptible (as judged by the number of bacteria inhibited). Indeed, the methanolic extract inhibited $75 \%$ of the gram positive bacterial species screened, compared to $40 \%$ of the gram negative bacteria. This is consistent with many previous studies with other plant species which report a greater susceptibility of gram positive bacteria towards solvent extracts for South American, ${ }^{30}$ African, ${ }^{31,32}$ and Australian ${ }^{33}$ plant extracts. Results within this laboratory ${ }^{10-34-36}$ have also confirmed the greater susceptibility of gram positive bacteria towards many other Australian plant extracts, although examples of Australian plants having a greater effect on gram negative bacteria have also been reported. ${ }^{37,38}$

Our study examined the ability of $S$. formosa leaf extracts to inhibit the growth of a panel of medicinally important bacterial pathogens. The methanolic and aqueous extracts were identified as being particularly potent inhibitors of $P$. mirabilis with MIC values of 141 and $168 \mu \mathrm{g} /$ $\mathrm{mL}$ respectively. As $P$. mirabilis can trigger rheumatoid arthritis in genetically susceptible individuals. ${ }^{28,29}$ these extracts have potential for the development of rheumatoid arthritis preventative therapies. The methanolic and aqueous extracts were also potent $K$. pneumoniae growth inhibitory properties, with MIC values 166 and $375 \mu \mathrm{g} / \mathrm{mL}$ respectively. As K. pneumoniae can trigger ankylosing spondylitis in genetically susceptible individuals, ${ }^{24}$ this extract may also be useful in the prevention of ankylosing spondylitis.

The methanolic and aqueous $S$. formosa leaf extracts also were moderate to good inhibitors of several other bacterial pathogens. Both the aqueous and methanolic $S$. formosa leaf extracts were also good inhibitors of $A$. faecalis, A. hydrophilia, B. cereus, S. aureus and S. pyogenes growth with MIC values generally $300-1000 \mu \mathrm{g} / \mathrm{mL}$. As these bacteria have been implicated in a number if gastrointestinal and skin diseases, the aqueous and methanolic $S$. formosa leaf extracts also may have applications in the treatment of these diseases.

Whilst a detailed investigation of the phytochemistry of the S. formosa leaf extracts was beyond the scope of our study, qualitative screening studies were used to determine the classes of compounds present. Several commonalities were noted: the most potent aqueous, methanolic and ethyl acetate extracts all contained relatively high levels of phenolics, tannins and flavonoids. Many studies have reported potent growth inhibitory activities for a number of tannin compounds. Gallotannins have been reported to inhibit the growth of a broad spectrum of bacterial species ${ }^{39}$ through a variety of mechanisms including binding cell surface molecules including lipotoichoic acid and proline-rich cell surface proteins, ${ }^{40,41}$ and by inhibiting glucosyltransferase enzymes. ${ }^{42}$ Elligitannins are also highly potent inhibitors of bacterial growth, 
with MIC values as low as $62.5 \mu \mathrm{g} / \mathrm{mL} \cdot{ }^{39-41}$ Ellagitannins have also been reported to function via several antibiotic mechanisms including interaction with cytoplasmic oxidoreductases and by disrupting bacterial cell walls. ${ }^{39,41}$ Thus, it is likely that $S$. formosa leaf tannins may contribute to the inhibition of bacterial growth reported in our study.

It is likely that other phytochemical classes may also contribute to the growth inhibitory properties of these extracts. Our qualitative phytochemical screening studies indicate that polyphenolics and flavonoids were present in the $S$. formosa leaf extracts in high levels. Many studies have reported potent antibacterial activities for a wide variety of polyphenolic compounds, including many flavonoids. ${ }^{43}$ Furthermore, alkaloids were detected in low to moderate levels in the inhibitory extracts. This is noteworthy as the alkaloids swainsonine and DMT have both previously been reported in Swainsona spp. Extracts. ${ }^{9-13}$ Swainsonine induces toxicity by inhibiting $\alpha$-mannosidase and mannosidase II activity, ${ }^{10}$ which subsequently inhibits glycoprotein processing and maturation. Many pathogenic bacteria incorporate $\mathrm{N}$-glycosylically linked surface proteins $s^{11,12}$ and thus swainsonine may affect bacterial growth. However, this is yet to be adequately tested. Of further note, several DMT derivatives have potent antimicrobial activity ${ }^{14}$ and thus may also contribute to the inhibitory activity reported in our study. Further studies are required to test these compounds for growth inhibitory activity against the bacterial pathogens screened in our study. It would be particularly interesting to test swainsonine and DMT for the growth inhibition against B. cereus, K. pneumoniae and P.mirabilis. Furthermore, bioactivity driven isolation of active components is required to confirm the bioactive components and to further evaluate the mechanism of bacterial growth inhibition.

The findings reported here also demonstrate that all of the $S$. formosa leaf extracts were nontoxic towards Artemia franciscana nauplii, with $24 \mathrm{~h}$ $\mathrm{LC}_{50}$ values substantially $>1000 \mu \mathrm{g} / \mathrm{mL}$. Extracts with $\mathrm{LC}_{50}$ values $>1000$ $\mu \mathrm{g} / \mathrm{mL}$ towards Artemia nauplii are defined as being nontoxic. ${ }^{27}$ Whilst our preliminary toxicity studies indicate that these extracts may be safe for therapeutic use, studies using human cell lines are required to further evaluate the safety of these extracts. Furthermore, as both swainsonine and DMT have psychoactive properties, studies are needed to evaluate the potential negative side effects of these extracts. Whilst these studies have demonstrated the potential of the $S$. formosa leaf extracts in the development of future antibiotic chemotherapeutics for the prevention and treatment of urinary tract infections, autoimmune diseases (particularly rheumatoid arthritis and ankylosing spondylitis) and some gastrointestinal and skin diseases, more work is required to isolate the inhibitory components and determine the mechanism of inhibition.

\section{CONCLUSIONS}

The results of this study demonstrate the potential of the S. formosa leaf extracts as inhibitors of pathogenic bacteria growth. Furthermore, their lack of toxicity indicates than they may be safe for therapeutic treatment. Further studies aimed at the purification and identification of bioactive components are needed to examine the mechanisms of action of these agents.

\section{ACKNOWLEDGEMENTS}

The authors are grateful to Philip Cameron for providing the plant material used in this study. We are also grateful to Michelle Mendell and Jane Gifkins for the gift of the clinical isolate bacterial strains. Financial support for this work was provided by the Environmental Futures Research Institute and the School of Natural Sciences, Griffith University, Australia.

\section{CONFLICTS OF INTEREST}

The authors report no conflicts of interest.

\section{ABBREVIATIONS}

DMSO: Dimethyl sulfoxide; $\mathrm{LC}_{50}$ : The concentration required to achieve $50 \%$ mortality; MIC: minimum inhibitory concentration.

\section{REFERENCES}

1. Monroe S, Polk R. Antimicrobial use and bacterial resistance. Current opinion in microbiology. 2000;3(5):496-501

2. Hübsch Z, Van Zyl RL, Cock IE, Van Vuuren SF. Interactive antimicrobial and toxicity profiles of conventional antimicrobials with Southern African medicinal plants. South African Journal of Botany. 2014;93:185-97.

3. Cock IE. Medicinal and aromatic plants-Australia. Ethnopharmacology section, Biological, Physiological and Health Sciences, Encyclopedia of Life Support Systems (EOLSS). Developed under the auspices of UNESCO. Oxford, UK: EOLSS Publishers; 2011. Available from: http://www.eolss.net. Accessed 1 April 2013."

4. Kalt FR, Cock IE. Gas chromatography-mass spectroscopy analysis of bioactive Petalostigma extracts: Toxicity, antibacterial and antiviral activities. Pharmacognosy Magazine. 2014;10:(S37-49)1. DOI: 10.4103/0973-1296.127338.

5. Courtney R, Sirdaarta J, Matthews B, Cock IE. Tannin components and inhibitory activity of Kakadu plum leaf extracts against microbial triggers of autoimmune inflammatory diseases. Pharmacognosy Journal. 2015;7(1):18-31.

6. Wright $\mathrm{MH}$, Sirdaarta J, White A, et al. Bacillus anthracis growth Inhibitory Properties of Australian Terminalia spp.: Putative Identification of low Polarity Volatile Components by GC-MS Headspace Analysis. Pharmacognosy Journal. 2016;8(3): 281-90. DOI: 10.5530/pj.2016.3.18.

7. Cock IE, WinnettV Sirdaarta J, Matthews B. The potential of selected Australian medicinal plants with anti-Proteus activity for the treatment and prevention of rheumatoid arthritis. Pharmacognosy magazine. 2015;(Suppl 1):S190-208. DOI: 10.4130/0973-1296.157734.

8. Lassak EV, Mc Carthy T. Australian Medicinal Plants. Australia: Reed New Holland Publishers, Australia; 2011.

9. Grum DS, Cook D, Baucom D, Mott IW, Gardner DR, Creamer R, Allen JG. Production of the alkaloid swainsonine by a fungal endophyte in the host Swainsona canescens. Journal of natural products. 2013;76(10):1984-8

10. Goss PE, Reid CL, Bailey D, Dennis JW. Phase IB clinical trial of the oligosaccharide processing inhibitor swainsonine in patients with advanced malignancies. Clinical cancer research. 1997;3(7):1077-86

11. Dwivedi R, Nothaft H, Reiz B, Whittal RM, Szymanski CM. Generation of Free Oligosaccharides from Bacterial Protein N-Linked Glycosylation Systems. Biopolymers. 2013;99(10):772-83

12. Nothaft H, Szymanski CM. Protein glycosylation in bacteria: sweeter than ever Nature Reviews Microbiology. 2010;8(11):765-78

13. Nankervis D. Law proposal claims Sturt's Desert Pea as dangerous as marijuana. Sunday Mail 2011; 19 March. http://www.topix.com/forum/world/australia/ TCLBPPAUQGDD1JMVFAccessed 2/6/2016.

14. Lira NS, Montes RC, Tavares JF, et al. Brominated compounds from marine sponges of the genus Aplysina and a compilation of their $13 \mathrm{C}$ NMR spectral data. Marine drugs. 2011;9(11):2316-68.

15. Arkhipov A, Sirdaarta J, Rayan P, Mc Donnell PA, Cock IE. An examination of the antibacterial, antifungal, anti-Giardial and anticancer properties of Kigelia africana fruit extracts. Pharmacognosy Communications. 2014;4(3):62-76. DOI: 10.5530/pc.2014.3.7.

16. Vesoul J, Cock IE. The potential of Bunya nut extracts as antibacterial functional food agents. Pharmacognosy Communications. 2012;2(1):72-9. DOI: 10.1111/ ijfs. 13026

17. Hart C, llanko P, Sirdaarta J, et al. Tasmannia stipitata as a functional food/natura preservative: Antimicrobial activity and toxicity. Pharmacognosy Communications. 2014;4(4):33-47. DOI: 10.5530/pc.2014.4.4

18. Cock IE. Antimicrobial activity of Acacia aulacocarpa and Acacia complanta methanolic extracts. Pharmacognosy Communications 2012;2(1):66-71. DOI: 10.5530/pc.2012.1.12

19. Wright MH, Matthews B, Arnold MS, Greene AC, Cock IE. The prevention of fish spoilage by high antioxidant Australian culinary plants: Shewanella putrefaciens growth inhibition. International Journal of Food Science \& Technology. 2016. DOI: $10.1111 /$ iifs. 13026

20. Sautron C, Cock IE. Antimicrobial activity and toxicity of Syzygium australe and Syzygium leuhmannii fruit extracts. Pharmacognosy Communications. 2014;4(1):53-60. DOI: 10.5530/pc.2014.1.8

21. Cock IE, van Vuuren SF. South African food and medicinal plant extracts as potential antimicrobial food agents. Journal of Food Science and Technology. 2015;52(11):6879-99. DOI: 10.1007/s13197-015-1806-3

22. Vesoul J, Cock IE. An examination of the medicinal potential of Pittosporum phylliraeoides: toxicity, antibacterial and antifungal Activities. Pharmacognosy 
Communications. 2011;1(2):8-17. DOI: 10.5530/pc.2011.2.3.

23. Cock IE. Antimicobial activity of Callistemon citrinus and Callistemon salignus methanolic extracts. Pharmacognosy Communications 2012; 2(3): 50-57. DOI: 10.5530/pc.2012.3.11. DOI: 10.5530/pc.2011.2.3.

24. Cock IE, van Vuuren SF. The potential of selected South African plants with antiKlebsiella activity for the treatment and prevention of ankylosing spondylitis. Inflammopharmacology. 2015;23(1):21-35. DOI: 10.1007/s10787-014-0222-z.

25. Cock IE, Ruebhart DR. Assessment of the toxicity of selected Australian native plant extracts using the Artemia franciscana nauplii bioassay. The Internet Journal of Toxicology. 2008;5(2):2.

26. Ruebhart DR, Wickramasinghe W, Cock IE. Protective efficacy of the antioxidants vitamin $\mathrm{E}$ and Trolox against Microcystis aeruginosa and microcystin-LR in Artemia franciscana nauplii. Journal of Toxicology and Environmental Health Part A. 2009;72(24):1567-75.

27. Cock IE, Ruebhart DR. Comparison of the brine shrimp nauplii bioassay and the ToxScreen-II test for the detection of toxicity associated with Aloe vera (Aloe barbadensis Miller) leaf extract. Pharmacognosy Research 2009; 1(2): 98-101.

28. Cock IE, van Vuuren SF. Anti-Proteus activity of some South African medicinal plants: their potential for the prevention of rheumatoid arthritis. Inflammopharmacology. 2014;22(1):23-36. DOI: 10.1007/s10787-013-0179-3.

29. Ebringer A, Rashid T. Rheumatoid arthritis is an autoimmune disease triggered by Proteus urinary tract infection. Journal of Immunology Research. 2006;13(1):41-8.

30. Paz EA, Cerdeiras MP, Fernandez J, Ferreira F, Moyna P, et al. Screening of Uruguayan medicinal plants for antimicrobial activity. Journal of Ethnopharmacology. 1995;45(1):67-70

31. Kudi AC, Umoh JU, Eduvie LO, Gefu J. Screening of some Nigerian medicinal plants for antibacterial activity. Journal of Ethnopharmacology. 1999;67(2):2258.

32. Vlietinck AJ, van Hoof L, Totte J, Lasure A, Vanden Berghe D, et al. Screening of hundred Rwandese medicinal plants for antimicrobial and antiviral properties.
Journal of Ethnopharmacology. 1995 Apr 1;46(1):31-47.

33. Palombo EA, Semple SJ. Antibacterial activity of traditional Australian medicinal plants. Journal of ethnopharmacology. 2001;77(2):151-7.

34. Cock IE, Kukkonen L. An examination of the medicinal potential of Scaevola spinescens: Toxicity, antibacterial, and antiviral activities. Pharmacognosy Research. 2011;3(2):85-94. DOI: 10.4103/0974-8490.81955.

35. Cock IE, Mohanty S. Evaluation of the antibacterial activity and toxicity of Terminalia ferdinandia fruit extracts. Pharmacognosy Journal. 2011;3(20):72-9.

36. Kalt FR, Cock IE. The medicinal potential of Australian native plants from Toohey Forest, Australia. The South Pacific Journal of Natural and Applied Sciences. 2011 Feb 10;28(1):41-7.

37. Mohanty S, Cock IE. Evaluation of the antibacterial activity and toxicity of Myrciaria caulifloria methanolic leaf and fruit extracts. Internet J Microbiol. 2009;7(2).

38. Winnett V, Boyer H, Sirdaarta J, Cock IE. The potential of Tasmannia lanceolata as a natural preservative and medicinal agent: Antimicrobial activity and toxicity. Pharmacognosy Communications. 2014;4(1):42-52. DOI: 10.5530/pc.2014.1.7.

39. Buzzini P, Arapitsas P, Goretti M, Branda E, Turchetti B, Pinelli P, et al. Antimicrobial and antiviral activity of hydrolysable tannins. Mini Reviews in Medicinal Chemistry. 2008;8(12):1179-87.

40. Wolinsky LE, Sote EO. Isolation of natural plaque-inhibiting substances from 'Nigerian chewing sticks'. Caries Research. 1984;18(3):216-25.

41. Hogg SD, Embery G. Blood-group-reactive glycoprotein from human saliva interacts with lipoteichoic acid on the surface of Streptococcus sanguis cells. Archives of Oral Biology. 1982;27(3):261-8

42. Wu-Yuan CD, Chen CY, Wu RT. Gallotannins inhibit growth, water-insoluble glucan synthesis, and aggregation of mutans streptococci. Journal of Dental Research. 1988;67(1):51-5.

43. Cock IE. The phytochemistry and chemotherapeutic potential of Tasmannia lanceolata (Tasmanian pepper): A review. Pharmacognosy Communications 2013:3(4):13-25. DOI: 10.5530/pc.2013.4.3.

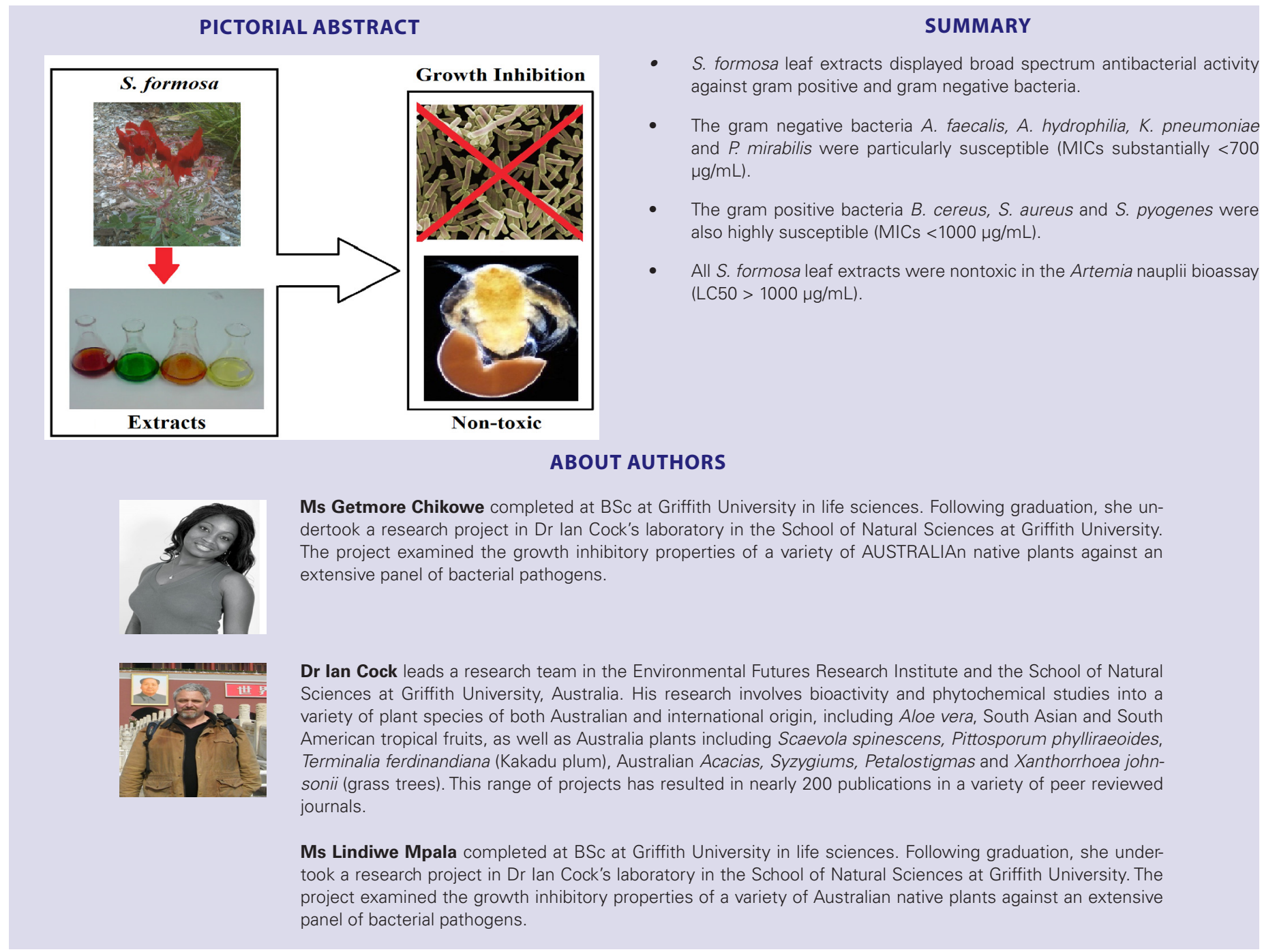

